International Journal of Education, Learning and Development

Vol. 10, No.1, pp.1-15, 2022

Print ISSN: 2054-6297(Print)

Online ISSN: 2054-6300 (Online)

\title{
THE IMPRESSION OF TECHNOLOGY EDUCATION ON THE GRAPHIC DESIGN PROGRAMME AT TAKORADI TECHNICAL UNIVERSITY
}

\author{
Ebenezer Kofi Enninful \\ Department of Graphic Design Technology, Takoradi Technical University \\ Abraham Boakye-Amponsah \\ Department of Graphic Design Technology, Takoradi Technical University
}

\begin{abstract}
The study sought to find out the influence of today's Technology on the Graphic Design programme being pursued by Higher National Diploma (HND) students at the Department of Graphic Design Technology. This is against the background that Technology forms an integral part of the Graphic Design programme in the $21^{\text {st }}$ century. An in-depth review of related literature from various authors have been discussed concerning the study. Through non-probability purpose sampling, an aggregate of 134 students and teaching staff were selected for the study. The research methodology employed for the study included the use of participant observation and questionnaire to reveal key findings for the study. This was complemented with proper structured and semistructured interview techniques to beseech views from respective respondents for practical analysis. Consequently, the researchers' findings from the data revealed that Technology had had some level of impacts on the Graphic Design programme. Based on the findings the researchers have made appropriate recommendations to help include the contemporary trends in the Technology for the Graphic Design programme in the technical university to prepare students adequately with the requite hands-on training as the Graphic Design industry in Ghana and beyond demands; although the importance and the practices cannot be over emphasised.
\end{abstract}

KEYWORDS: graphic design, technology, impact, programme, trends, computer graphics

\section{INTRODUCTION}

Gyau \& Obiri - Yeboah (2011) stated that, "the concept of Graphic Design simply means birth of a skill-oriented career where all forms of visuals are used to communicate effectively. It is the rationale behind one's ability to create something out of nothing with the ultimate goal of informing, projecting or announcing a message in an organized format”. Meggs (2002), also defines Graphic Design as the art and profession of selecting and arranging visual elements such as typography, images, symbols and colours to convey a message to an audience. More so, Hollis (1994), defines Graphic Design as a form of visual communication. More precisely it is the business of making or choosing marks and arranging them on a surface to convey an idea. Given the outlined definitions from different authors', the researchers believed Graphic Design can be defined as an important tool for communicating to both the illiterates and literates especially with the fact that it has to do with visual communication. Nonetheless, "Technology is the application

@ECRTD-UK https://www.eajournals.org/

https://doi.org/10.37745/ijeld.2013 
of science, engineering and industrial organization to create a human-built world", (Alfred and Richard, 1999). Mokyr (1990), stated that, "By technology progress and advancement the researchers meant, any change in the application of information to the production process in such a way as to increase efficiency, resulting either in the production of a given output with fewer resources (i.e lower cost), or the production of better or new products". Graphic Design has been all about technology since computers were invented years ago. Technology is the heartbeat of a Graphic Designer. Before computers were invented, Graphic Design was done manually in terms of making of postcards, call cards, posters, banners, signposts, signboards, greeting cards and many more. According to Meggs (2002), Graphic Design has been practiced in various forms throughout history. Indeed, strong examples of Graphic Design date back to manuscripts in ancient China, Egypt and Greece. As printing and book production developed in the $15^{\text {th }}$ Century, advances in graphic design developed alongside it over subsequent centuries with compositors or typesetters often designing pages as they set the type. Graphic Designers were by then used to stenciling, block printing and illustrating manually with their hands. Meggs (2002) stated that, "in the late $19^{\text {th }}$ century, Graphic Design emerged as a distinct profession in the West, because of the job specialization process that occurred there and partly because of the new technologies and commercial possibilities brought about by the Industrial Revolution".

In the late $19^{\text {th }}$ and early $20^{\text {th }}$ centuries, advertising agencies, book publishers and magazines hired art directors who organized all visual elements of the communication and brought them into a whole. In 1922, a typographer William A. Dwiggins coined the term Graphic Design to identify the emerging field. Thus, the transition of graphic design with the introduction of Computer Technology into the system. Throughout the $20^{\text {th }}$ century, the technology available to designers continued to advance rapidly as did the artistic and commercial possibilities for design. Indeed, the technology of using computers for designing was unavailable in the few tertiary known institutions and, in the country, as far back as the last quarter of the $20^{\text {th }}$ century.

By $21^{\text {st }}$ century, Graphic Design had become a global profession as advanced technology and industry spread throughout the world. The evolution of Graphic Design as a practice and profession has been closely bound to technical innovations, societal needs and the visual imagination of practitioners. In the words of Meggs (2002), "now in the $21^{\text {st }}$ century, technology has really improved the outcome of works done by Graphic Designers, in terms of printing, photography and more". With the introduction of technology, work has been made easy. Graphic Designers work faster and effective and can produce large number of works at a goal. Technology as we all know has an upper hand in the Graphic Design sector, and if not upgraded personally could make an individual left behind time and progression. Graphic design with Computer Technology training for HND students at the Department of Graphic Design Technology of the Faculty of Applied Arts and Technology, Takoradi Technical University which hitherto was practically oriented is now being boosted and enhanced with $21^{\text {st }}$ century software and series of applications for effective teaching and learning. Consequently, there is the need for the evaluation of how Computer Graphics technologies have made influence in the Graphic Design programme which will in turn

@ECRTD-UK https://www.eajournals.org/ https://doi.org/10.37745/ijeld.2013 
help graphic design students have knowledge about the impact technology has on the programme being it positive or negative.

\section{Statement of the Problem}

Considering the artistic developmental need of the country, the three year Higher National Diploma in the Commercial Art Programme (Graphic Design) was set up to meet the growing demands by the industry. Based on this fact, it has been observed that Takoradi Technical University lacks when it comes to the wide range of technologies linked to the Graphic Design programme. As a result, students lack the knowledge about most of these computing technologies with new trends, therefore lacking the knowledge of the impact of technology on Graphic Design for the vibrant industry. Due to this, students do not see or value the essence of the use of much technology, neither do they value the core and the need to upgrade them. Since the Higher National Diploma in Commercial Arts (Graphic Design) was introduced in the year 1995, only the Computer and software applications such Photoshop and Corel draw were introduced to students, making them limited in knowledge and hands-on skills and depriving them the knowledge of the impact of a wide range use of current trends with technology. Due to these facts, the researchers therefore believed there are the need to study and research into the role current technology plays and the impact it has on the Graphic Design programme students are studying and the benefits the industry will derived from students.

\section{Objectives of the research}

1) Identify the effect of Technology in the Graphic Design Programme.

2) Assess the various Computer Graphics equipment in the department's laboratory.

3) Identify the importance and the uses of Technology in the Graphic Design Programme at Takoradi Technical University.

\section{LITERATURE/THEORETICAL UNDERPINNING}

Mork (1994), states that the history of Graphic Design dates back to days when drawings were made on the cave walls and decoration made on pottery. The term and profession Graphic Design and Graphic Designer respectively came up in the 20th century. (Gyau \& Obiri - Yeboah, 2011) stated that, "the concept of graphic design simply means birth of a skill-oriented career where all forms of visuals are used to communicate effectively. It is the rationale behind one's ability to create something out of nothing with the ultimate goal of informing, projecting or announcing a message in an organized format". Meggs (2002) also defines Graphic Design as the art and profession of selecting and arranging visual elements such as typography, images, symbols and colours to convey a message to an audience. Hollis (1994), also defined graphic design as a form of visual communication. More precisely it is the business of making or choosing marks and arranging them on a surface to convey an idea.

Based on the definitions above, the researchers are of the view that, graphic design is all about art, skills and visual communication. Looking at the practical nature of Graphic Design and what it

@ECRTD-UK https://www.eajournals.org/

https://doi.org/10.37745/ijeld.2013 
entails, Hollis (1994), made a point that it is more precisely the business of choosing and arranging marks and this is done for the purpose of conveying messages to a target group. In view of all that have been outlined, graphic design is an essential tool for communicating to both illiterates and literates due to the fact that it communicates visually. The profession gained popularity in book design and general print design. Typography technology developed in the early $20^{\text {th }}$ century when designers claimed fonts, logos and stamps as their own. Graphic Design became famous as a result of advertising, packaging and printing. Graphic design firms sprung up leading to the setting up of the first Graphic Design School- Bauhaus, founded in 1919 in Germany. In the 1980s, computers begun to be used, it became the standard for Graphic Design. Bonsiepe (1994) writes that by tradition it is known that the Graphic Designer is mainly a "visualizer", one who organizes visual components that are then reproduced with the aid of printing technology. Subsequently, among the list of objects of professional actions we find: logotypes, stationary, book and magazine layout, advertisement and campaigns, exhibitions, displays corporate identity systems and signage systems. Most of the project works of students fall under these categories of works thus these students could also be referred to as "visualizers" because they organize and reproduce visual components with the aid of technology to bring out their works.

Margolin (2000) in a journal concerning graphic design says that graphic design does not have a fixed meaning; it was first used by the American book and advertising designer W. A. Dwiggins in 1922. During that period, Graphic Design was a profession about typography, book design or advertising design. By the mid $20^{\text {th }}$ century designers worked on large scale, they got involved in exhibitions, urban signage projects and corporate identity programmmes which brought about the term communication design. There has been additional improvement especially in the digital realm where designers make use of text, images, sound and others which work hand in hand with film making and sound design. These days many products (graduates) of the Department of Graphic Design, Takoradi Technical University find themselves in firms and companies making use of digital visuals as well as sounds in their daily demands, hence the name Communication Design in the $21^{\text {st }}$ century instead of Graphic Design in some state owned and private institutions. As regards to this, technology plays a very much significant role in Graphic Design. According to Margolin (2000), some of the things that make current Graphic Design different from that of earlier times include the proliferation of new media and software. According to him, designing good web sites, for example, requires a deeper understanding of cognitive psychology, learning theory, and other social science disciplines than most communication designers have.

\section{Some Technological Advancements in Graphic Design}

Holly (2012), in an article talks about the advancement of graphic design said that, Graphic Design has come a long way from its days on a letterpress and that technology has aided design at every turn and made it increasingly more straightforward, shareable, and powerful. He made it clear that design benefits from programmes like the Adobe creative suite and innovations with technology like online file storage have only fueled the power of graphic design. According to Holly (2002), previously graphic designers depended on web developers to help create websites. While designers could easily create effective layouts and beautiful contents, they need more than just design

@ECRTD-UK https://www.eajournals.org/ https://doi.org/10.37745/ijeld.2013 
experience to make their sites interactive. Designers had to learn computer and coding languages or hand over their work to more technological savvy collaborators. But today, Adobe systems have delivered an update to its Web creation tool for designers, one of them is the code-named Muse Beta 3. This helps graphic designers access the web. Adobe Muse can enable Graphic Designers according to Holly (2002) to create and publish professional Websites without writing code or working within restrictive templates. Already a success, more than 260,000 designers downloaded the technology in the first 40 days after it was developed. This shows the advancement and how ready graphic designers are to adapt to technological progress. Another technological advancement shared by Holly (2002) is, 'Cloud Computing'. Designers put a ton of effort into creating engaging, quality work. However, large files can be complicated to handle. Designers with high quality files and complex work quickly find that emails are not powerful enough to move those files around. Designers had to transport large files physically, mailing flash drives back and forth. Now, designers have the luxury of cloud computing. By storing their work online, they cannot only deal with much larger files but also share it with anyone that has an internet connection. Recently, FedEx and Google Docs (companies) teamed up to make cloud computing and printing even more collaborative computing has been a hugely helpful tool for boosting designers' work, their presence, and their reach.

The "Adobe Creative Suite", is also a software application for designers that continually evolve. The progressive software keeps designers on their toes by rolling out an update every 18-24 months. These updates make the Creative Suite (which includes Illustrator, Photoshop Extended, Flash Professional, InDesignee, Fireworks, Dreamweaver, Flash Catalyst, Bridge, Drive Central and Acrobat) more intuitive and vaster. It allows graphic designers, animators, and artists to create precisely what they intended and create it faster.

Updates to the new software are impressive. The programme has new tools such as perspective drawing for Illustrator and a touch-sensitive brush for Photoshop. It is a great time to be a Graphic Designer and the growing ability of design technology will free designers to become true designers instead of technicians.

\section{Technology and its influence on Graphic Design in modern times}

Amber (2012) stated that, "As technology continues to change at a mind-blowing pace, we should not be surprised that Graphic Design evolves right along with it." As a result, at this stage the researchers take a look at what impact technology has had on graphic design, as well as view a few examples of today's graphic design. Graphic design has been evolving and changing throughout the years, often redefining the definition of form and functionality while it does so. But why has graphic design changed so rapidly in the last decade? Thanks to the ever-rapidly developing technology used to create, display, and even print graphics and art. People are seeing designers push themselves as well as the boundaries as to what we define as Graphic Design. Noble and Bestley (2004) stated that, "It is clear that the designer's field of operation (a phrase the researchers have borrowed from the Dutch Graphic Designer educator, Jan Van Toom) has

@ECRTD-UK https://www.eajournals.org/ https://doi.org/10.37745/ijeld.2013 
changed considerably in recent years. A major influence on this has been, and continuous to be, technology".

Amber (2012) further stated that, thanks to the advent of faster, more powerful computers and faster internet, we expect our graphics to be of higher quality. We as viewers expect more colours, higher resolutions, and more detailed designs, because our computers can handle these graphics; whereas even as little as five years ago, designers had to be mindful of what they could unload onto us. Now we fully expect art and design that seem to jump right out of our computer monitors, signage, or product packaging. Thanks to graphic tablets, new design software, and advances in printing, designers can really get creative and one can design almost everything without limitation. To these imagine how much faster a graphic designer can create things with a tablet, rather than using a mouse to do all of their work. And of course, with design suites like Adobe Creative Suite, illustrators and much more updated software feature robust options for designers to utilize in new and often unexpected ways. Now that technology has branched out, it has offered designers hundreds of programmes to choose from, there are almost as many methods of graphic design as there are graphic designers out there.

Amber (2012) further noted that, "sure we want more colours and more details, but some of the best designs offer something more: immersion. People expect to be pulled in by a design, whether it is product packaging or a movie poster, web design or digital art. We expect our graphic designers to utilize the powerful technology around them to create a world at a glance. After all, isn't it nicer to browse a website that feels like it tells a story about a company, product, or individual rather than browsing one that feels very sterilized and cold?" As designers we also receive most of our work through electronic means be that e-mail, portfolio websites or just through forums, drop box and the likes.

"With a traditional paper portfolio, it is rarely possible to accommodate all our works, with a laptop we can take everything," (Shaughnessy 2010). This piece of Shaughnessy brings us to the light of how technology has made it easy for works of graphic designers to either be kept or sent to clients, especially with the fact that, one can now stay far and still have works done.

With this "Shaughnessy 2010" has further enlightened us on the impact of technology on graphic design. Dealing with press impacts, Ausrine (2008), stated that "new technology has had a significant impact on the field of graphic design because of printers and scanners, internet and designing programmes". Printers used in the printing industry as of now have the ability to print high resolution images, blending inks together to create true-to-life representations of what you see on a computer monitor, allowing for bolder designs on more materials than ever before. Today, designers and printers could run over a thousand copies without delay. Finishing, binding and cutting of copies printed works are done with complete ease and less caution is taken. This has been possible and achievable due to the advanced technology of equipment, machinery, software applications and the likes via computer technology applications in graphic design.

@ECRTD-UK https://www.eajournals.org/ https://doi.org/10.37745/ijeld.2013 
So far, as regards the research topic, it has been proven that technology has great impact on Graphic Design through:

1) The introduction of computers and their accessories, printers, cameras and many more to do work at the press and studios easier.

2) The introduction of the internet has enabled graphic designers to do more research pertaining to their work, thus deriving ideas and concepts from other creative designers all around the globe.

3) The introduction of several software programmes designed for graphic designers to make their works look more realistic and appealing. It has also enabled colourful works to be seen all over the social-media platforms for countless forms of advertising and promotions and the likes. Thanks to advances in technology, printers, animators, artists, photographers, typographers, web designers and designers et cetera are developing varied methods and styles that continually impress and appeal to many people around the globe.

\section{RESEARCH METHODOLOGY}

The study employed a case study approach with a combination of the relevant aspect of quantitative and qualitative research methods to gather comprehensive views and experiences of respondents for a better understanding of the influence of technology on the graphic design programme in the department. Plowright (2010) participant-as-observer methodology and face-toface semi-structured interview with designated lecturers and students were the main instruments used in collecting primary data for the study. The qualitative analysis took the form of interpreting specialized views and content analysis of interviews and documents, while quantitative analysis took the form of description statistics such as correlations, frequencies and percentages supported with very few relevant Tables.

Specifically, the non-probability purposive sampling procedure was used. According to Onwuegbuzie and Leech (2007), with the non-probability purposive sampling technique, a researcher chooses respondents who are thought to be of most relevance to the survey and takes appropriate steps to reach the sample. In this regard, the purposive sampling was used to select one hundred and twenty-eight (128) students from levels 200 and 300 respectively pursuing Graphic Design programme with six (6) teaching staff in the department. Hence, they are at a better position to outline the impact of the Graphics Technology in their studies. All $128(100 \%)$ copies of set of questionnaires were retrieved and analyzed.

\section{RESULTS AND DISCUSSION}

This section of the study analyses in detail the data obtained from the survey, uses very few tables to diagrammatically depict the findings. The data analyses were undertaken with focus on the set objectives. The analyses involved making comparisons of variables measured and finding connections between variables; the identification, description and discussion of various sample

@ECRTD-UK https://www.eajournals.org/ https://doi.org/10.37745/ijeld.2013 
proportions (the proportions of respondents in the sample with certain characteristics) among other things. Nevertheless, the response rate for the study was $100 \%$.

\section{Demography Characteristics of targeted respondents}

Concerning the number of years students have studied graphic design, the findings show that respondents who have studied Graphic Design for 4-5 years are 3rd years. To probe further, they stated that some of them had studied this course earlier before being enrolled into the Technical University Education. Those who studied it for 1-2 years are both the 2nd and 3rd year students. With the number of years respondents have studied the course and have been exposed to the use of Computer Graphics Technology enough to know the kind of impact it has had on the course they study thus they have not been exposed to computer education that much.

As regards the number of years lecturers have taught Graphic Design technology related courses the data shows that $3(50 \%)$ of the selected teaching staff in the department have had experience for more than ten years and are well equipped with theoretical and practical skills knowledgebased in Graphics Technology. This is an indication that such staff have much experience so far as computer related technology in their respective courses are concerned. More so, 2(33\%) have teaching experience in the programme whereas $1(17 \%)$ has up to 4 years teaching experience in the same discipline. The data is an indication that Technology is predominant in most of the courses thought in the department. It is an integral parts of the department's programme.

\section{The Impression of Technology on the Graphic Design Programme}

It emerged from the data on the part of the teaching staff that $4(66 \%)$ of the respondents specified that they integrate Technology in their courses for as stipulated in the programme. One (17\%) said they accommodate it for few minutes. The response from the remaining percentage 1(17\%) was that they do not include it in the courses they teach since it is not included in the curriculum. Furthermore, 6(100\%) of the teaching staff strongly agreed to the fact that Technology is incorporated into the curriculum in the courses they teach. The courses included; Packaging Technology, Printmaking Technology Adverting Technology, Computer Graphics, Typography, Photography, Printing Technology and Camera Operation.

As regards whether Technology is incorporated into the Graphic Design curriculum, it was evident from the data that students (both $2^{\text {nd }}$ and $3^{\text {rd }}$ years respectively) who strongly agreed were $102(80 \%)$. To the knowledge of the researchers, although some first years have been introduced to Technology Education earlier prior to their university admission, they have little exposure as compared to both the 2nd and 3rd years who have had it for 2-3years respectively. The remaining $26(20 \%)$ who responded otherwise disagreed that just diminutive of the Technology is incorporated in the various courses being offered in the Department of Graphic Design Technology.

In connection with data of the number of students who have been exposed and had had an encounter with Technology, interestingly all 128 respondents have an idea of what Technology is

@ECRTD-UK https://www.eajournals.org/

https://doi.org/10.37745/ijeld.2013 
and its impact it has on the courses they are studying under the Graphic Design Programme. Even more interesting is respondents in the $3^{\text {rd }}$ year; according to them they have had some level of exposure with the usage of Technology before starting the course in the Department of Graphic Design. The data gathered from respondents indicated that 29(23\%) of the $2^{\text {nd }}$ years agreed that they had had experience with the usage of Technology earlier; whereas 41(32\%) by another section of the $2^{\text {nd }}$ years were of the similar view while $58(45 \%)$ of the $3^{\text {rd }}$ years shared similar opinion that they have had opportunity with the practice of technology. This is an indication that students pursuing the Graphic Design Programme in the department have some level of experience and knowledge in the practices of Technology in the numerous courses. The researchers presumed this is a good fundamental representation of the knowledge based of the programme and its positive and average significant impacts on the students in the department despite some major challenges that need to be addressed. Therefore, the direction via which the department have been preparing its students to fit into the $21^{\text {st }}$ century on the job market in the graphic design industry is laudable and should be sustained. It also implies that the department is doing well to meet the needs of the industry demands in this rapid changing world. For instance, in terms of software application to manipulate designs at a faster and easiest way to implement ideas for clients.

With reference to teaching staff years on the exposure to modern Technology related applications in the various courses they lecture the data revealed that $1(17 \%)$ had had the practice of Technology for up to 10 years while 3(50\%) have an exposure on the course for between 11-16 years; whereas only $2(33 \%)$ had exposure over 20 years. This is an indication that selected staff who handle the students pursuing HND in Graphic Design have a lot of exposure in terms of the requite technology knowledge based. This is to impact appropriate hands-on training in terms of the Graphics Technology skills to their students vis-à-vis the current trends of Technology as the industry expects graphic design graduates to be well equipped with all the intrinsic worth associated therein. Furthermore, it suggests that the department has the right requisite lecturers to handle the Technology related knowledge and skills to effect the technical know-how to students involved to fit well in the job markets after graduation.

\section{Computer Graphics equipment in the department's laboratory}

Table 1: Adequate equipment in the department's laboratory

\begin{tabular}{|l|l|l|}
\hline Answer variation & Frequency & Percentage (\%) \\
\hline Strongly disagree & 24 & 19 \\
\hline Strongly agree & 104 & 81 \\
\hline Total & $\mathbf{1 2 8}$ & $\mathbf{1 0 0}$ \\
\hline
\end{tabular}

Source: Authors' Field Survey (2021)

The above data indicate the respondents' views as regards Table 1. It shows $24(19 \%)$ strongly disagree that equipment found at the department are obsolete and need replacement to reflect the current trends of modern graphic design laboratory to befit the department. However, the remaining 104(81\%) strongly agree that equipment currently displayed and being used by both

@ECRTD-UK https://www.eajournals.org/ https://doi.org/10.37745/ijeld.2013 
lecturers and students are archaic and need immediate replacement. The equipment presently at the department's laboratory include desktop computers (old-fashioned), and a projector. Through Plowright's observer-as-participant methodology (2010), the researchers observed that the existing computer laboratory room which takes a maximum of 51 students is too small to accommodate the current number of HND levels 200 and 300 Graphic Design students respectively. Per the data available to the researchers the existing number of HND level 200 is 307 students and that of those in HND level 300 is 234 students. It must be emphasized though that, each of these levels of students' class sizes have been divided into three equal parts $2 \mathrm{~A}, 2 \mathrm{~B}, 2 \mathrm{C}, 3 \mathrm{~A}, 3 \mathrm{~B}$ and $3 \mathrm{C}$. Therefore, any time there is Computer Graphics course the research revealed that the class size is further divided into shift system by the lecturers involved so as to have proper teaching and learning sessions. This is an indication that the department of Graphic Design needs major changes in the Computer Graphics Laboratory to meet the growing learning trends and enable its students acquire the needed skills to be effective and efficient in the ever-changing Graphic Design Industry in Ghana and beyond. The changes could include a bigger space to accommodate the growing number of graphic design students in the department; the expansion of various facilities in the department's laboratory. It behooves on the department to take the task to ensure that the department computer laboratory is transform to meet the current trends of the course.

In the $21^{\text {st }}$ century, every tertiary institution needs adequate and well-equipped studios, laboratories, workshops and others for proper demonstrations to impact the right knowledge to their students. Again, it is to enable the students have the hands-on training to enable them acquire the technical know-how to be able to fit into the sections of the industry. Moreover, using Plowright (2010) participant-as-observer methodology the researchers noted that, Graphic Design Department of the university is not to be well equipped to translate adequate Graphics Technology knowledge based to its students. In view of this, the researchers of the study wanted to know from respondents if the Department of Graphic Design are using the needed equipment to run the Computer Graphics course. Subsequently, the respondents indicated that the department has some general equipment that keep the Computer Graphics laboratory running. More so, internet connectivity in the department is sporadic thereby affecting quality teaching and learning processes on regular basis.

However, the lecturers believe modern equipment could be procured by the university to augment the existing ones available at the department. The respondents (students) conceived that there are a lot more the department can do to enhance the teaching and learning of the computer graphics technology on the Department of Graphic Design.

There is one scanner in the department which is not in good shape thereby affecting the quality delivery of some computer related skills. More so, 51 desktop computers available to the department is outmoded which hitherto are not in good shape. A respondent asserted to the fact that the department lacks necessary equipment to adequately prepare students for the job market in the industry. On the other hand, a respondent was of the view that the department lacks some modern technological advancement equipment for better implementation of the Computer

@ECRTD-UK https://www.eajournals.org/

https://doi.org/10.37745/ijeld.2013 
Graphics Technology in the Graphic Design Programme. For better and effective teaching and learning of the computer education technology related skills, there should be adequate computer logistics to assist the teaching of the course in the department. Other respondents were of the view that the equipment needed to make teaching and learning effective include desktop computers, scanners, printing machines, cameras, studio projectors, high speed internet connectivity and others.

\section{Perceptions of what Students and Lecturers think has changed about Graphic design over the years}

The data gathered gives valid accounts on what respondents' think have changed about Graphic Design programme over the years in the department. Fifty-eight (45\%) of the respondents assumed that, Graphic Design has changed over the years concerning Technology due to the introduction of new software. Hence, $38(30 \%)$ of the students were of the view that inclusion of technology in the graphic design programme is encouraging and help students learn and work faster. This avowal by the students is more so, buttressed by Meggs (2002), "now in the $21^{\text {st }}$ century, technology has really improved the outcome of works done by Graphic Designers, in terms of printing, photography and more". In addition, 32 (25\%) students alleged that, the invention of computers, equipment and various technologies brought about the change in Graphic Design in relation to technology.

Few decades ago, teaching and learning of graphic design in tertiary institution in Ghana were done manually. They included animation, photography, print making, typography, advertising, packaging and many more, but now graphics technology software have taken augmented the graphic design sector and has put a halt to some manual works that took several hours to be executed. Graphic Design is now much easier and faster in relation to the use of Graphics Technology associated software. According to the respondents, it has brought about speed, accuracy and effectiveness of work into the graphic design industry. As a result, the graphic design industry is able to execute more works within a short time and in good quality as well. Once more, this claim is also reinforced by Meggs (2002), "now in the $21^{\text {st }}$ century, technology has really improved the outcome of works done by Graphic Designers, in terms of printing, photography and more".

On the contrary the data reveal interesting statistics on this issue. Two-thirds (67\%) of the respondents believed that nothing much has changed over the years as far as the teaching of Graphic Design is concerned and that they still use the old ways. Nonetheless, the one-third of the lecturers thought that, the change about Graphic Design programme in the department over the years is that students being trained now are not able to acquire much knowledge and the technical know-how so far as the demands and the trends of the industry are concerned. This might be for the fact students do not have access to enough equipment which would make requisite impact on the students' studies. Accordingly, the use of participant-as-observer in the department's computer laboratory suggests that much have changed in terms of delivery by the teaching staff but not 
limited to the various accessories that go a long way to improve the teaching of the technology related issues.

\section{Importance and Uses of Computer Technology in the Graphic Design Programme}

Two different views were given by students as regards this particular item, which sort to unearth ways to make use of Technology in their course work. The discoveries show that, 25(20\%) of the respondents shared views stating that, they make use of Technology by the use of installed software on their computers and by the use of the internet to research under the various courses. One hundred and three (80\%) stated that, they also make use of Technology by using it to design packages, in the photography discipline for editing; and in the printing for designing layouts, in the advertising course for designing posters, signage et cetera. Considering the diverse views, respondents attested making use of Technology in their various courses of study including the use of software such as the Adobe Photoshop, Corel draw and Adobe illustrator to design. The above finding is supported by Margolin (2000), "some of the things that make current Graphic Design different from that of earlier times include the proliferation of new media". Nevertheless, it must be emphasized that this few software being learnt by the students are not enough to meet the everchanging world in the graphic design discipline. Although, the current graphic design curriculum which was sketched years ago provides the above to be used to teach the students, the trends have changed rapidly in the last decade.

However, the data from the lecturers shows that $5(83 \%)$ talked about using the software applications such as Adobe Photoshop and Illustrator, Sketch, Motion Graphics, Affinity Designer, CorelDraw, et cetera in lecturing, demonstrating, online teaching and assessment and the use of the internet to carry out their research. This assertion is strengthened by Amber (2012), "thanks to the advent of faster, more powerful computers and faster internet, we expect our graphics to be of higher quality. We as viewers expect more colours, higher resolutions, and more detailed designs, because our computers can handle these graphics; whereas even as little as five years ago, designers had to be mindful of what they could unload onto us". More so, 1(17\%) shared their view using gadgets such as the projector and laptops as a helping aid in their day-to-day lectures. On the part of the students, respondents were asked to state the practical and theoretical knowledge and skills they have acquired from the use of computer technology in the course they studied. Few respondents stated that, they have yet not acquired any form of skill since they came to $2^{\text {nd }}$ year not long ago.

In the words of Philip B. Meggs (2002), "now in the $21^{\text {st }}$ century, technology has really improved the outcome of works done by Graphic Designers, in terms of printing, photography and more". Three (2\%) stated that practically, they have learned how to manage time and also how to meet deadlines of works and projects assigned to them by their lectures. Eighty-five (61\%) of the students emphasized that they have acquired skills through the use of different kinds of software. Eight (6\%) stated that theoretically, they have learnt that it is not right to use a person's image without his or her knowledge even if it is of good use or even if it will benefit the individual hence, permission must be sort before using someone's image. Five (4\%) stated that they acquired

@ECRTD-UK https://www.eajournals.org/ https://doi.org/10.37745/ijeld.2013 
theoretical and practical knowledge in photography, printing technology, advertising technology, typography on how to use the camera and its equipment. Seventeen students gained creativity and thinking ability whereas $(15 \%)$ of them stated categorically that, they could generate concepts and design at a short-given time. There were few $(9 \%)$ respondents stated that, they are now familiar with any kind of equipment that is associated with their course work. Hence, students' ability to fathom the evolved technology in the graphic design programme is encouraging.

\section{Challenges faced with Technology in the Graphic Design Programme}

Indeed, every new innovation comes with its challenges nevertheless, as times go on the identified challenges are resolved by the innovators. Despite the main objectives having been dealt with extensively in the earlier discussions, some challenges as regards the Technology in the Graphic Design programme cannot be unheeded. The data revealed that 39(30\%) talked about the regular update needed in their day-to-day activities of the technology education. If their systems are not updated, they fall behind time. In addition, 61(48\%) find it difficult in terms of the manipulation of tools associated with technology. Software including Motion Graphics, Adobe After Effects, Adobe Illustrator, Premiere Pro and Adobe Photoshop, 28(22\%) of the respondents itemized that it is quite expensive since most software applications are not for free and have to be purchased from a source online. This is bolstered by the "Adobe Creative Suite", a software application for designers that continually evolve. It allows graphic designers, animators, and artists to create precisely what they intended and create it faster.

Furthermore, the study identifies some challenges associated with the technology on the Graphic Design programme since its implementation two decades ago. The study disclosed that all the desktop computers in the computer laboratory have major challenges as regards their core functions to assist students to learning and practicing. Consequently, students are requested to attend lectures with their own laptops. It was expected that the current desktops in the said department's laboratory would have been replaced long ago. This would have enabled students who cannot afford laptops yet have desired to learn and practice the courses could fall on those at the laboratory until such a time they can afford themselves.

The researchers based on the current industry supervision experiences asserted that in the $21^{\text {st }}$ century, the industry players including managers and employers require or in some cases hire or employ the services of Graphic Designers who have the ability and skill to use software (Motion graphics, After Effect, Premier Pro, InDesign, Adobe illustrator, Adobe Photoshop etc) to manipulate and creatively design or arranging all kinds of visual elements for the general public consumption in wide areas such packaging, advertising, photography, printing and others. Indeed, these are the skills and competencies managers of the various firms in the sector require or expect from students. This is vital for the industry's rapid growth. These are few claims the industry players are purported to make when supervisors visit various firms for assessing students on internship by the department during the long vacation holidays.

@ECRTD-UK https://www.eajournals.org/

https://doi.org/10.37745/ijeld.2013 
In addition to the above challenges, the respondents narrated other views in connection to the above issues that affect the delivery of technology on the graphic design programme. Fifty-one (40\%) expressed having less adequate facilities such as the computers for constant practice whereas 34(26\%) complained about finding difficulties in understanding the concepts of software. They also find it difficult especially for the fact that the lecturers do not teach to their understanding. Even so, 19(15\%) find challenges with it when they lose works and documents due to regular system breakdown and computer virus attacks and the likes.

\section{Implication to Research and Practice}

As a result of the of the findings of this study, the researchers suggest to the university through department to make effort and install modern facilities and equipment at the department's computer laboratory for students' study via online research and practice. In practice, the installation of the contemporary equipment will assist students to be on top of modern trends as regards the theory in technology which are developed for use on daily basis. For advanced research, the technology in Graphic Design programme should be revised to reflect the contemporary trends (Affinity Design, Adobe Illustrator CC, Inkscape, InDesign, Premiere Pro et cetera) in the course in the $21^{\text {st }}$ century. Furthermore, that it should be mandatory as a policy by the department for all first years to possess laptops as soon as they are admitted into the department for intense practical and theoretical research in the field of study. This will enable the ministry of education aim of making the technical/vocation education in the technical universities of acquiring hands on training such as graphic design students to be fulfilled.

\section{CONCLUSION}

The research revealed that Technology Education had had impact on the Graphic Design Programme despite the numerous challenges including the fact that the content of the course needs to be urgently reviewed to reflect the contemporary trends in the Graphics industry in the $21^{\text {st }}$ century. Hence, the inculcation of technology on the programme needs to be sustained. The programme according to the data gathered from the respondents has helped in the acquisition of skills, made working easy, made learning more effective and also has paved way for students to be employed in the graphic design industry after graduation.

\section{Recommendations}

The use of technology had had impact since it was incorporated in the Graphic Design programme. Based on the findings, the researchers recommend to the university through department to make effort and install modern facilities and equipment at the department's computer laboratory for students' study. Furthermore, that it should be mandatory for first years to get laptops as soon as they are admitted into the department. The technology in Graphic Design programme should be revised to reflect the contemporary trends (Affinity Design, Adobe Illustrator CC, Inkscape, InDesign, Premiere Pro and many others in the course in the $21^{\text {st }}$ century).

@ECRTD-UK https://www.eajournals.org/

https://doi.org/10.37745/ijeld.2013 
International Journal of Education, Learning and Development

Vol. 10, No.1, pp.1-15, 2022

Print ISSN: 2054-6297(Print)

Online ISSN: 2054-6300 (Online)

\section{Future Research}

Based on the research findings the researchers suggest a further study can be carried out in a different direction to unearth other interesting findings in the Graphic Design programme at the department.

\section{REFERENCES}

Alfred, Richard 1999, p.19 Visions of Technology: A Century of Vital Debate About Machines Systems and the Human World Bonsiepe

Bashir, Z., \& Dasti, R. ( 2015). Demographic Correlates of Poly-Victimization in Street Children of Lahore City. Journal of the Indian Academy of Applied Psychology, suppl. Special Issue; Chennai Vol. 41, Iss. 3, ., 194-202.

GROPPERS, R. ( 2008, NOVEMBER 19). Senior Seminar. Retrieved from BLOG ARCHIVE: https://sseminar08.blogspot.com/2008/11/rachel-groppers-answers.html

Hub, B. (2011). The Influence of Technology on Graphic Design. Bright Hub. Retrieved https://www.brighthub.com/multimedia/publishing/articles/121403/

Ian, N. and Bestley, R. (2004). An Introduction to Research Methodologies, AVA Publishing.

Kayleighmahon. (2012, October 20). Literature review - the impact of digital technologies on the graphic design practice. Retrieved from $\mathrm{Km}$ Graphic Designer: https://kayleighmahon.wordpress.com/2012/10/20/literature-review-the-impact-ofdigital-technologies-on-the-graphic-design-practice/

Leech, N. L. and Onwuegbuzie, A.J. (2007). Sampling Designs in Qualitative Research: Making the Sampling Process More Public.

Margolin, G. (2000). The Effects of Family and Community Violence on Children.

Martin Hollis (1994). The Philosophy of Social Science, Cambridge: Cambridge University Press.

Meggs P. B. and Heller, S. (2000). The History of Graphic Design and Becoming a Graphic Designer, Toronto: John Wiley and Sons

Meggs, P. B. (2021, April 9). Graphic design. Retrieved from Britannica: https://www.britannica.com/art/graphic-design

Mokyr, J. (1990). Lever of Riches: Technological Creativity and Economic Progress, New York: Oxford University Press

Ploywright, D. (2010). Using Mixed Methods Frameworks for Integrated Methodology, London: Sage Publications

Shaughnessy, A. (2010). How to be a Graphic Designer Without Losing Your Soul: Laurence King

@ECRTD-UK https://www.eajournals.org/

https://doi.org/10.37745/ijeld.2013 